\title{
Plasma nitrogen isotopic fractionation and feed efficiency in growing beef heifers
}

\author{
N. M. Wheadon ${ }^{1,2}$, M. McGee ${ }^{1}$, G. R. Edwards ${ }^{2}$ and R. J. Dewhurst ${ }^{1 *}$ \\ ${ }^{1}$ Animal and Grassland Research and Innovation Centre, Teagasc, Grange, Dunsany, County Meath, Republic of Ireland \\ ${ }^{2}$ Faculty of Agriculture and Life Sciences, PO Box 84, Lincoln University, Lincoln, New Zealand \\ (Submitted 10 July 2013 - Final revision received 19 November 2013 - Accepted 20 November 2013 - First published online 6 January 2014 )
}

\section{Abstract}

Fractionation of $\mathrm{N}$ isotopes occurs in many metabolic reactions which causes tissue proteins to become enriched in ${ }^{15} \mathrm{~N}$ while urea (urine) is depleted in ${ }^{15} \mathrm{~N}$ relative to the diet. We investigated ${ }^{15} \mathrm{~N}$ enrichment of whole plasma and its relationship with feed conversion efficiency (FCE) in growing beef heifers ( $n$ 84) offered $2 \mathrm{~kg} / \mathrm{d}$ of concentrates with grass silage ad libitum. Heifers were on average 299 (SD $48 \cdot 3$ ) d old and weighed 311 (SD 48.8) kg. Plasma was obtained on day 79 ( $n$ 84) of the experiment and from a subset of animals ( $n$ 20) on four occasions between days 16 and 79. Silage DM intake (DMI) averaged 4.1 (SD 0.74 ) kg/d and concentrate DMI was $1.72 \mathrm{~kg} / \mathrm{d}$. Mean mid-test live weight was 333 (SD 47.6) kg, daily gain was 0.53 (SD 0.183) kg, FCE (g live-weight gain/g DMI) was 0.09 (SD 0.028) and residual feed intake (RFI) was $0($ SD 0.428$)$. N isotopic fractionation $\left(\Delta^{15} \mathrm{~N}\right.$; plasma $\left.\delta^{15} \mathrm{~N}-\operatorname{diet} \delta^{15} \mathrm{~N}\right)$ averaged $3.58 \% 0$ on day $79(n 84)$ and $3.90 \% 0$ for the subset of heifers. There was no relationship between $\Delta^{15} \mathrm{~N}$ and RFI. Plasma $\delta^{15} \mathrm{~N}$ and $\Delta^{15} \mathrm{~N}$ were related to both FCE (negative) and animal weight (positive) for the whole population, and repeatable for the subset of animals over four time points. These relationships of $\Delta^{15} \mathrm{~N}$ with FCE and animal weight are consistent with the anticipated negative relationship with N-use efficiency. There is potential to use $\Delta^{15} \mathrm{~N}$ to provide rapid, low-cost estimates of FCE in cattle.

\section{Key words: Beef cattle: Nitrogen-15: Isotopic fractionation: Feed efficiency}

Livestock industries around the world face the partially contradictory objectives of increasing production of meat and milk to match growing demand, while also reducing environmental impact and greenhouse gas emissions ${ }^{(1)}$, all within a resourceconstrained setting. In particular, there is pressure to reduce $\mathrm{N}$ excretions because of new environmental legislation ${ }^{(2)}$. Improvements in feed efficiency are essential for the beef farmer because of increasing costs of production; feed is the largest variable cost and an important determinant of profitability in beef production ${ }^{(3)}$. Identification of, and genetic selection for, feed-efficient cattle is an important approach to achieve these multiple objectives ${ }^{(4)}$. Improvements in feed efficiency have already been successful in other species; for example, there was a $20 \%$ increase in feed efficiency in poultry between 1996 and $2003^{(5)}$.

Feed conversion ratio, defined as the ratio of feed intake: live-weight gain $^{(6)}$, and feed conversion efficiency (FCE), defined as the units of output per unit of feed ${ }^{(7)}$, are traditional measures of feed efficiency commonly used in assessing beef cattle. Residual feed intake (RFI), defined as the difference between an animal's measured feed intake and expected intake based on its weight and average daily gain, is an alternative method of measuring feed efficiency in beef cattle, and is independent of growth rate and live weight ${ }^{(8)}$.

Incorporation of feed efficiency measurements into cattle breeding strategies has been slow ${ }^{(4)}$. Feed efficiency is costly and laborious to measure, even with automated systems. It is necessary to record feed intake and growth over at least $70 \mathrm{~d}$ in order to have accurate estimates of efficiency ${ }^{(9)}$, and it is not possible to easily apply this approach to grazing animals ${ }^{(10)}$. There is also uncertainty about the composition of body reserves and liveweight change, as well as nutrient requirements for pregnancy which make these measurements even more difficult, especially with pregnant and (or) lactating animals ${ }^{(11)}$.

More recently, there has been an increased interest in longerterm strategies of genetic and genomic selection for feed efficiency or its components such as digestive efficiency, metabolic efficiency or animal activity ${ }^{(12)}$. Success in identifying genetic and genomic associations with complex traits such as feed efficiency depends on being able to measure the phenotype in large numbers of animals representing a broad crosssection of genetic variation ${ }^{(13)}$. A number of studies have sought biochemical markers for feed efficiency (measured as $\mathrm{RFI}^{(14-16)}$ ) in response to these difficulties. Unfortunately,

Abbreviations: $\Delta^{15} \mathrm{~N}$, plasma $\delta^{15} \mathrm{~N}-\operatorname{diet} \delta^{15} \mathrm{~N}$; DMI, DM intake; FCE, feed conversion efficiency; NUE, nitrogen-use efficiency; RFI, residual feed intake. 
these markers have only been poorly correlated with feed efficiency measurements. These relationships may have been influenced by physiological factors including dietary intake, digestibility, metabolism of nutrients, physical activity and thermoregulation $^{(17)}$, and external factors such as environment and health ${ }^{(18)}$. Identification of phenotypic markers can also be used to aid in constructing diets to match the energy requirements of cattle and compare the efficiency of nutrient use for different diets.

We have investigated an alternative marker for feed efficiency based on the phenomenon of $\mathrm{N}$ isotopic fractionation ${ }^{(19)}$ that occurs during a number of metabolic pathways. $\mathrm{N}$ isotopic fractionation occurs when the incorporation of the natural isotopes ${ }^{14} \mathrm{~N}$ and ${ }^{15} \mathrm{~N}$ into products is slightly different from their ratio in precursors because of differences in the mass of small compounds containing either ${ }^{14} \mathrm{~N}$ or ${ }^{15} \mathrm{~N}$. As a result of $\mathrm{N}$ isotopic fractionation, urine is depleted in ${ }^{15} \mathrm{~N}$ relative to the diet, while animal proteins are enriched ${ }^{(20-22)}$. In particular, enrichment of tissue protein occurs during transamination and deamination reactions in the conversion of excess dietary protein into urea ${ }^{(23)}$, protein turnover and recycling ${ }^{(22,24)}$ and rumen metabolism ${ }^{(25)}$. The magnitude of fractionation depends on the efficiency of assimilation ${ }^{(24)}$ and metabolic rate $^{(26)}$ and varies between tissue type and metabolic pools ${ }^{(27,28)}$. $\mathrm{N}$ fractionation has been a useful predictor of $\mathrm{N}$ partitioning in non-ruminants, e.g. measurements in plasma protein from rats ${ }^{(29)}$ and hair protein from horses, cattle and goats $^{(30)}$. There have also been previous reports of the use of $\mathrm{N}$ isotopes to investigate the effects of changing dietary protein in beef cattle ${ }^{(30)}$, the mechanisms of fractionation in ruminal microbes $^{(25)}$ and for predicting nitrogen-use efficiency (NUE) in dairy cattle ${ }^{(31)}$.

$\mathrm{N}$-use efficiency, defined as the efficiency of converting feed $\mathrm{N}$ into animal protein $\mathrm{N}$, is an important component of overall feed efficiency ${ }^{(32)}$, as muscle protein is the most valuable component of the carcass in beef cattle. Since body composition was not measured in the present study, we have related $\mathrm{N}$ isotopic fractionation to overall FCE. We expect a strong relationship between NUE and FCE, particularly when offering the same diet. The adjustments involved in calculating RFI and other more complex measures of feed efficiency make them less likely to be related to $\mathrm{N}$ isotopic fractionation than simple measures of input/output such as FCE investigated in this work.

The objective of the present study was to investigate the relationship between $\mathrm{N}$ isotopic fractionation, measured in plasma, and estimates of FCE in growing beef heifers. We also investigated the repeatability of $\mathrm{N}$ isotopic fractionation over a 3-month period and hypothesised that there would be no change in the relationship between $\mathrm{N}$ isotopic fractionation and FCE over time.

\section{Materials and methods}

\section{Animals and their management}

All animal procedures performed in the present study were conducted under experimental licence from the Irish
Department of Health and Children in accordance with the Cruelty to Animals Act 1876 and the European Communities (Amendment of Cruelty to Animals Act 1876) Regulation 2002 and 2005. The present study used plasma samples from eighty-four beef heifers (sixty-two Simmental and twentytwo Simmental $\times$ Holstein-Friesian) sampled on one occasion towards the end of a period of recording FCE. A subset of twenty heifers from the same population (fifteen Simmental and five Simmental $\times$ Holstein-Friesian) was sampled over four time points spaced across the FCE recording period. Further details of the original study have been described by Lawrence et al. ${ }^{(16)}$. The heifers were on average 299 (SD 48.3) d old and weighed 311 (SD 48.8) kg at the start of the experiment. They were housed in pens of four to six animals (lying area $2.87 \mathrm{~m}^{2}$ /animal) in a shed with slatted floors and adapted to their diet for 3 weeks before a 12-week recording period. Heifers were individually offered grass silage $\mathrm{ad}$ libitum and were fed $2 \mathrm{~kg} / \mathrm{d}$ concentrates (at 08.00 hours) through Calan gates (American Calan, Inc.). Daily feed intakes were recorded and animals were weighed at 3-week intervals.

\section{Sample collection and analysis}

Blood samples were obtained by jugular venepuncture from all animals on day 79, and from the subset of twenty animals on days 16, 37, 58 and 79 of the experimental period. The former samples were collected into $4 \mathrm{ml}$ evacuated tubes containing sodium citrate (Greiner Vacuette; Cruinn Diagnostics), while samples from the subset of twenty animals were collected separately into $9 \mathrm{ml}$ evacuated tubes containing lithium heparin (Greiner Vacuette; Cruinn Diagnostics). Blood samples were then centrifuged $\left(2500 \mathrm{~g}, 20 \mathrm{~min}, 4^{\circ} \mathrm{C}\right)$, and whole plasma was stored at $-20^{\circ} \mathrm{C}$ until analysis.

Grass silage and concentrate offered was sampled three and two times weekly, and composited weekly and fortnightly, respectively. These were analysed according to the methods described by Owens et al. ${ }^{(33)}$ with the exception that the DM content of the grass silage was determined after drying at $40^{\circ} \mathrm{C}$ for $48 \mathrm{~h}$. Samples of the concentrates and grass silage ( $n$ 20; all in duplicate), as well as plasma samples, measured in whole plasma ( $n 164$ plus 10\% duplicates) were analysed for ${ }^{15} \mathrm{~N}$ content by isotope-ratio MS (Iso-Analytical Limited). N-15 results are expressed in $\delta$ units relative to standard air $\left(\delta^{15} \mathrm{~N}\right.$, $\%$ ). $\mathrm{N}$ isotopic fractionation, the difference between $\delta^{15} \mathrm{~N}$ for plasma and $\delta^{15} \mathrm{~N}$ for the diet, is termed $\Delta \delta^{15} \mathrm{~N}$, or simply $\Delta^{15} \mathrm{~N}$. Average diet $\delta^{15} \mathrm{~N}$ was calculated for each animal by weighting $\delta^{15} \mathrm{~N}$ for silage and $\delta^{15} \mathrm{~N}$ for concentrate based on $\mathrm{N}$ intake $(\mathrm{g} / \mathrm{d})$ of each diet component.

\section{Statistical analysis}

RFI was calculated as the difference between actual DM intake (DMI) and expected DMI using regression models to predict $\mathrm{DMI}^{(16)}$. The relationships between plasma $\delta^{15} \mathrm{~N}, \Delta^{15} \mathrm{~N}, \mathrm{FCE}$, RFI and $W^{0.75}$ were described using linear regression (GenStat release 10.1; Lawes Agricultural Trust (Rothamsted Experimental Station), 2007) using breed as a factor in the model. ANOVA was used to establish the effect of breed and sire on $\mathrm{N}$ isotopic 
Table 1. Average chemical composition of feed samples collected over the experimental period

\begin{tabular}{lcc}
\hline & \multicolumn{2}{c}{ Diet component } \\
\cline { 2 - 3 } & Grass silage & Concentrate \\
\hline $\mathrm{DM}(\mathrm{g} / \mathrm{kg})$ & $244 \cdot 3$ & $85 \cdot 79$ \\
$\mathrm{pH}$ & $3 \cdot 9$ & $\mathrm{ND}$ \\
Composition of DM (g/kg DM, unless 0 otherwise stated) & \\
In vitro DMD* & 744 & 858 \\
In vitro DOMD $\dagger$ & 688 & $\mathrm{ND}$ \\
OMD & 762 & $\mathrm{ND}$ \\
Ash & 98 & 85 \\
Crude protein & 136 & 140 \\
$\mathrm{NDF}$ & 511 & 215 \\
Starch & $\mathrm{ND}$ & 269 \\
Fermentation characteristics $(\mathrm{g} / \mathrm{kg} ~ D M)$ & \\
Lactic acid & 43 & $\mathrm{ND}$ \\
Acetic acid & 80 & $\mathrm{ND}$ \\
Propionic acid & 4.9 & $\mathrm{ND}$ \\
Butyric acid & $12 \cdot 9$ & $\mathrm{ND}$ \\
Ethanol & $57 \cdot 4$ & $\mathrm{ND}$ \\
$\mathrm{NH} \mathrm{H}_{3}-\mathrm{N}$ (g/kg total $\left.\mathrm{N}\right)$ & 73 & $\mathrm{ND}$ \\
$\delta^{15} \mathrm{~N}(\%)$ & $5 \cdot 74$ & $3 \cdot 20$ \\
\hline
\end{tabular}

ND, not determined; DMD, DM digestibility; DOMD, digestible organic matter in total DM; OMD, organic matter digestibility; NDF, neutral-detergent fibre.

${ }^{*}$ Measured in vitro.

$\dagger$ Measured in vitro.

$\ddagger$ Measured in vitro.

fractionation and feed efficiency. Pearson's correlations were used to show the relationship of $\mathrm{N}$ isotopic fractionation between time points, and a REML repeated-measures model was used to analyse changes in the relationship between FCE and $\mathrm{N}$ isotopic fractionation over time.

\section{Results}

A total of eighty-six heifers commenced the experiment, but values were excluded from one sick animal and one extreme outlier (confirmed using Cook's test). These exclusions had no effect on the relationships identified. The average chemical composition of the grass silage and concentrates across the experiment is described in Table 1 . Across the whole population, average DMI was $5.82(\mathrm{SD} 0.74) \mathrm{kg} / \mathrm{d}$, silage DMI averaged 4.1 (SD 0.74$) \mathrm{kg} / \mathrm{d}$ and concentrate intake was $1.72 \mathrm{~kg} / \mathrm{d}$, so that the forage proportion of total DMI averaged $0.70(\mathrm{SD} 0.038) \mathrm{g} / \mathrm{g}$. Mean mid-test live weight was 333 (SD 47.6$) \mathrm{kg}$, average daily gain was 0.53 (SD 0.183 ) kg, FCE (g live-weight gain/g DMI) was 0.09 (SD 0.028) and average RFI was 0 (SD $0 \cdot 428$ ). For the subset of twenty heifers, the average DMI was $5.82(\mathrm{SD} 0.59) \mathrm{kg} / \mathrm{d}$, silage DMI averaged 4.1 (SD 0.59$) \mathrm{kg} / \mathrm{d}$ and concentrate was $1.72 \mathrm{~kg} / \mathrm{d}$, so forage proportion of the total DMI averaged $0.70(\mathrm{SD} 0.031) \mathrm{g} / \mathrm{g}$. Mean mid-test live weight was 339 (SD 53.7) kg, average daily gain was 0.55 (SD $0 \cdot 164) \mathrm{kg}$, average $\mathrm{FCE}$ was $0 \cdot 10$ (SD 0.030) and RFI was -0.079 (SD 0.472).

Although feed samples were drawn from the same batches, there was a slight variation in $\delta^{15} \mathrm{~N}$ values, so the average values were used in calculating $\Delta^{15} \mathrm{~N}$. The average $\delta^{15} \mathrm{~N}$ values of the concentrates and grass silage were $3 \cdot 20$ (SD 0.189) and 5.74 (SD 0.103)\%, and the weighted value for the whole diet was 4.96 (SD 0.082) \% for the subset of twenty animals and 4.95 (SD 0.098)\%o for all the eighty-four animals. Plasma $\delta^{15} \mathrm{~N}$ for each of the four time points averaged 8.85 (SD 0.43), 8.80 (SD 0.40), 8.84 (SD 0.41) and 8.69 (SD 0.48), respectively, ranging from a 3.04 to 5.11 unit enrichment relative to the diet. The average $\delta^{15} \mathrm{~N}$ of plasma for all the eighty-four animals at day 79 was 8.53 (SD 0.364)\%o, ranging from a 3.51 to $5 \cdot 14$ unit enrichment relative to the diet.

Although there was a small range in overall diet $\delta^{15} \mathrm{~N}$ (a consequence of the differences in the forage:concentrate ratio consumed), there was no significant relationship between diet $\delta^{15} \mathrm{~N}$ and plasma $\delta^{15} \mathrm{~N}$ for the whole population or any of the repeated time points for the subset of heifers. Linear regression analysis using data from all animals at day 79 , as well as for the subset of twenty animals at each of the four time points, showed a significant negative relationship between plasma $\delta^{15} \mathrm{~N}$ and FCE in each case (Table 2). $\mathrm{N}$ isotopic fractionation $\left(\Delta^{15} \mathrm{~N}\right)$ was also negatively related to FCE for all the sample time points (Fig. 1(a)-(e), equations 1-5). The subset showed stronger relationships than those observed for the whole population:

$$
\begin{aligned}
& \text { Day } 79(n=84): \Delta^{15} \mathrm{~N}=4 \cdot 216(\text { SE } 0 \cdot 101) \\
& -7 \cdot 36(\operatorname{SE~} 1 \cdot 10) \times \text { FCE }(\mathrm{g} / \mathrm{g})
\end{aligned}
$$

$$
\begin{aligned}
& \text { Day } 16(n=20): \Delta^{15} \mathrm{~N}=4 \cdot 781(\text { SE } 0 \cdot 231) \\
& -9 \cdot 33(\operatorname{sE} 2 \cdot 32) \times \text { FCE }(\mathrm{g} / \mathrm{g}) .
\end{aligned}
$$

$$
\begin{aligned}
& \text { Day } 37(n=20): \Delta^{15} \mathrm{~N}=4.743(\text { SE } 0.197) \\
& -9.49(\text { SE } 1.98) \times \text { FCE }(\mathrm{g} / \mathrm{g}) .
\end{aligned}
$$

Table 2. Coefficients of determination $\left(r^{2}\right)$ or coefficients of multiple determination $\left(R^{2}\right)$ for the relationships between feed conversion efficiency (g live-weight gain $/ \mathrm{kg}$ DM intake) and plasma $\delta{ }^{15} \mathrm{~N}, \Delta^{15} \mathrm{~N}$ (plasma $\delta{ }^{15} \mathrm{~N}-\operatorname{diet} \delta^{15} \mathrm{~N}$ ) and mid-test $W^{0.75}$, with average standard errors ${ }^{*}$

\begin{tabular}{lcccccc}
\hline & \multicolumn{5}{c}{ Day of experiment } \\
\cline { 2 - 6 } & 16 & 37 & 58 & $79(n 20)$ & $79(n 84)$ & SEM \\
\hline Plasma $\delta{ }^{15} \mathrm{~N}$ & 0.52 & 0.63 & 0.69 & 0.59 & 0.28 & 0.284 \\
$\Delta^{15} \mathrm{~N}$ & 0.47 & 0.56 & 0.64 & 0.56 & 0.35 & 0.284 \\
Plasma $\delta{ }^{15} \mathrm{~N}+$ mid-test $W^{0.75}$ & 0.81 & 0.83 & 0.84 & 0.74 & 0.44 & 0.22 \\
$\Delta^{15} \mathrm{~N}+$ mid-test $W^{0.75}$ & 0.72 & 0.71 & 0.75 & 0.68 & 0.41 & 0.244 \\
\hline
\end{tabular}

${ }^{*}$ All relationships were significant at the $P<0.001$ level. 
(a)

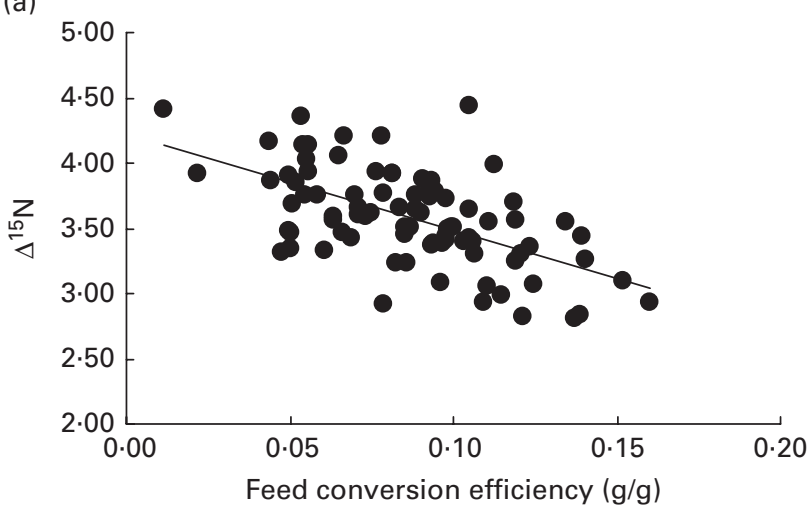

(c)

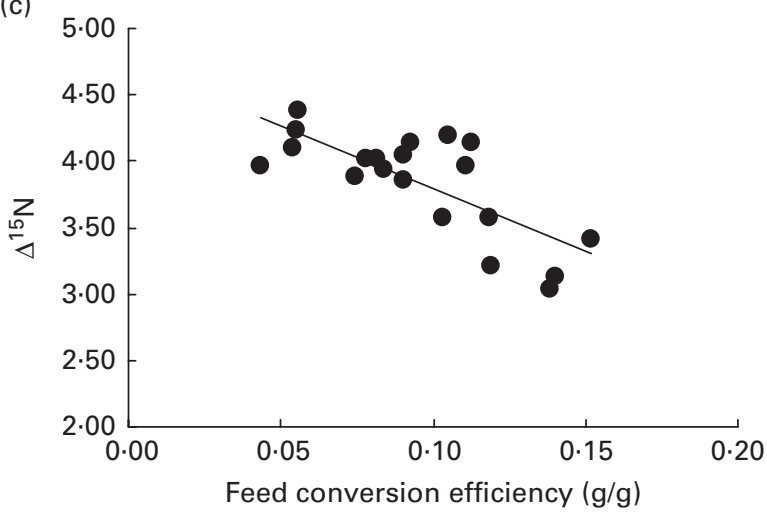

(b)

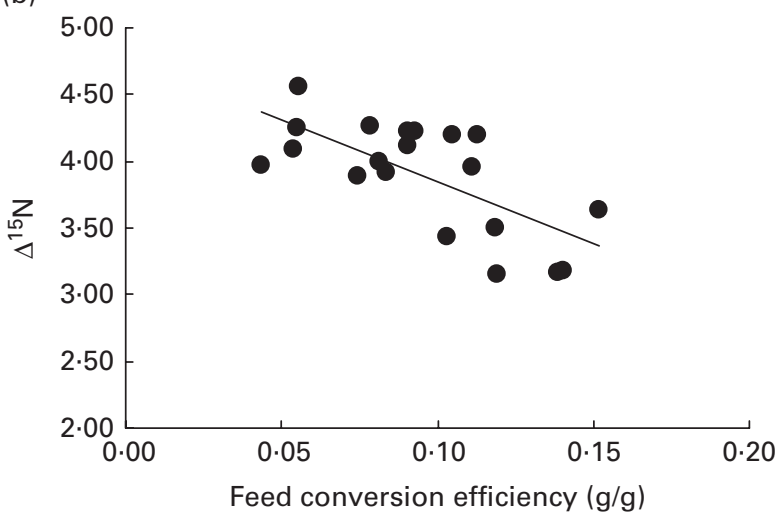

(d)

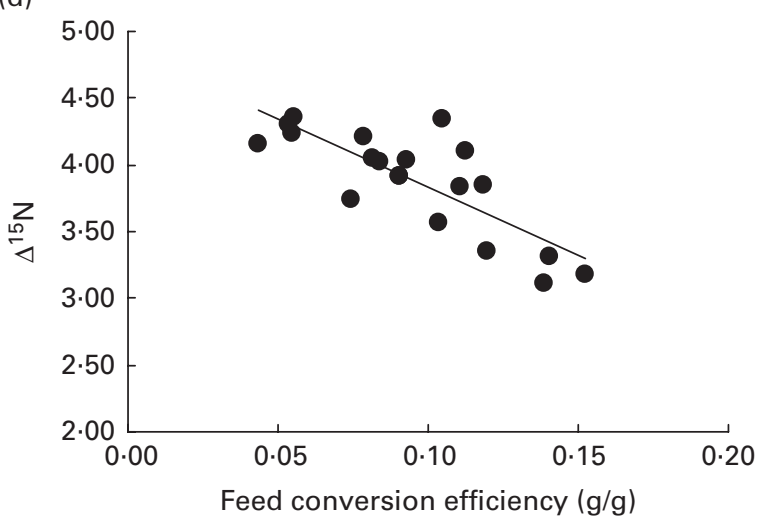

(e)

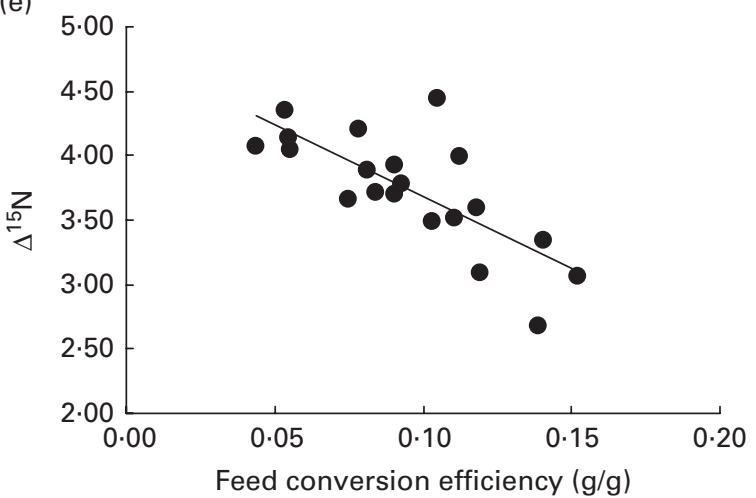

Fig. 1. Relationship between nitrogen isotopic fractionation $\left(\Delta^{15} \mathrm{~N}\right.$; the difference between plasma $\delta{ }^{15} \mathrm{~N}$ and diet $\left.\delta{ }^{15} \mathrm{~N}\right)$ and feed conversion efficiency (g live-weight gain/g DM intake) for (a) all animals at day $79\left(n 84 ; R^{2} 0.35\right)$ and (b)-(e) a subset of twenty animals at days $16\left(n 20 ; R^{2} 0.47\right), 37\left(n 20 ; R^{2} 0.56\right)$, $58\left(n 20 ; R^{2} 0.64\right)$ and $79\left(n 20 ; R^{2} 0.56\right)$.

Day $58(n=20): \Delta^{15} \mathrm{~N}=4 \cdot 854($ SE $0 \cdot 179)$

$-10 \cdot 25($ SE $1 \cdot 80) \times$ FCE $(\mathrm{g} / \mathrm{g})$.

Day $79(n=20): \Delta^{15} \mathrm{~N}=4 \cdot 789($ SE $0 \cdot 232)$

$-11 \cdot 11($ SE $2 \cdot 33) \times$ FCE $(\mathrm{g} / \mathrm{g})$.

There was no significant difference between the slopes on different days $(P=0 \cdot 848)$. Plasma $\delta{ }^{15} \mathrm{~N}$ measurements from the same animals in the subset were significantly correlated over adjacent time points $(P<0.001$ correlation between all days; average $r$ 0.96), and the degree of correlation for individuals decreased with greater time separation between samplings (e.g. $r$ 0.84 between the twenty animals on the first and last sampling dates).

There was no significant relationship between FCE and DMI $\left(r^{2} 0 \cdot 06 ; P=0 \cdot 16\right)$. There was a weak $\left(r^{2} 0 \cdot 10\right)$, but significant ( $P=0.002)$, negative relationship between FCE and mid-test metabolic weight $\left(W^{0.75}\right)$. Nonetheless, adding $W^{0.75}$ in a multiple regression analysis explained an additional and highly significant part of the variation in plasma $\delta^{15} \mathrm{~N}$ and $\Delta^{15} \mathrm{~N}$ across all time points (Table 2). There was no significant 
relationship either between plasma $\delta^{15} \mathrm{~N}$ and RFI $(P=0 \cdot 21$; $\left.r^{2} 0 \cdot 07\right)$, or between $\Delta^{15} \mathrm{~N}$ and RFI $\left(P=0 \cdot 82 ; r^{2} 0\right)$.

There was a significant difference in FCE between breeds in the present study $(P<0 \cdot 001)$. Pure Simmental heifers had lower FCE (0.076 (SD 0.003)) than Holstein-Friesian $x$ Simmental heifers (0.119 (SD 0.004)). Simmental heifers also had significantly higher plasma $\delta^{15} \mathrm{~N}(P<0 \cdot 001)$ and $\Delta^{15} \mathrm{~N}$ $(P<0.001)$ than Holstein Friesian $\times$ Simmental cross heifers (8.63 (SD 0.04) and 8.22 (SD 0.06); 4.38 (SD 0.04) and 3.92 (SD 0.06), respectively). Despite significant differences in FCE and N isotopes between breeds, there was no significant effect on the relationship between FCE and $\delta^{15} \mathrm{~N}$ or $\Delta^{15} \mathrm{~N}$. FCE $(\mathrm{g} / \mathrm{g})$ also differed across sire groups $(P<0 \cdot 001)$, ranging from $0 \cdot 06$ (sD 0.010) to 0.13 (SD 0.001). There were fifteen sires for the larger group and three sires for the subset group. Plasma $\delta^{15} \mathrm{~N}$ and, as a result, plasma $\delta^{15} \mathrm{~N}-\operatorname{diet} \delta^{15} \mathrm{~N}$ were significantly different between the sire groups $(P<0.001$ and $P<0 \cdot 001)$. Plasma $\delta^{15} \mathrm{~N}$ and $\Delta^{15} \mathrm{~N}$ ranged from $8 \cdot 17$ (SD $\left.0 \cdot 12\right)$ to 8.97 (sD 0.11 ) and 3.81 (sD 0.11) to 4.69 (sD $0 \cdot 10$ ) for different sire groups, respectively. Plasma $\delta^{15} \mathrm{~N}$ and $\Delta^{15} \mathrm{~N}$ tended to be higher in sire groups with lower FCE. FCE and average daily gain were slightly higher for the subset of twenty heifers compared with the whole population $(P<0.001$ and $P<0 \cdot 001$, respectively).

\section{Discussion}

NUE in cattle can be improved by increasing $\mathrm{N}$ retention in muscle at a similar intake, by reducing $\mathrm{N}$ intake at a similar $\mathrm{N}$ retention, or by a combination of both. Live-weight gain is the main driver for $\mathrm{N}$ retention in growing animals, and as muscle protein is the most valuable component of the carcass in beef cattle, it is essential to identify animals with higher NUE which will aid in lowering the impact of detrimental $\mathrm{N}$ emissions to the environment ${ }^{(1)}$. Phenotypic markers such as $\mathrm{N}$ isotopic fractionation used in the present study have potential to be used to measure feed efficiency in cattle where diet composition or intake cannot be recorded. This will accelerate collection of feed efficiency data for large numbers of animals in breeding programmes.

\section{Comparison of nitrogen isotopic fractionation with earlier studies}

$\mathrm{N}$ isotopic fractionation $\left(\Delta^{15} \mathrm{~N}\right)$ between whole plasma and the diet overall averaged 3.74 in the present study (range 3.04$5 \cdot 11 \% 0$ ), which is lower than the range measured previously with growing or mature ruminants $(3 \cdot 80-6 \cdot 94 \%$ for treatment means; Table 3). The plasma urea fraction is generally depleted in $\delta^{15} \mathrm{~N}$ compared with both the diet and the plasma protein fraction ${ }^{(22)}$. N fractionation can be measured in the plasma protein or urea $\mathrm{N}$ fraction of plasma; however, in the present study, whole plasma was used because the urea fraction contains less than $1 \%$ of the $\mathrm{N}$ in plasma, so the effect on results in the present study would be negligible. For the same reason, we calculate that the fact that the highest $\Delta^{15} \mathrm{~N}$ in the literature (Table 3) was for plasma protein is purely coincidental. There was only a weak relationship $\left(\begin{array}{lll}r^{2} & 0 \cdot 1\end{array}\right)$ between plasma urea $\mathrm{N}$ and FCE in the present study, which taken together with the low level of urea $\mathrm{N}$ relative to protein $\mathrm{N}$ in plasma suggests that the urea fraction of plasma would not affect the relationship between FCE and plasma $\delta^{15} \mathrm{~N}$.

While most previous studies provided only limited descriptions of the animals, many involved mature animals that would have ceased growing and so use dietary $\mathrm{N}$ relatively inefficiently, resulting in a high level of isotopic fractionation $\left(\Delta^{15} \mathrm{~N}\right)$. Lower $\Delta^{15} \mathrm{~N}$ were observed in studies with suckling young and in most, but not all, studies with lactating ruminants. It would be expected that these more productive animals would be using $\mathrm{N}$ more efficiently, partitioning a higher proportion of $\mathrm{N}$ to muscle or milk protein and less to urea.

Table 3. Literature values for nitrogen isotopic fractionation in ruminants $\left(\Delta^{15} \mathrm{~N} ; \delta^{15} \mathrm{~N}\right.$ in blood minus $\delta{ }^{15} \mathrm{~N}$ in the diet $)$

\begin{tabular}{|c|c|c|c|c|c|}
\hline Reference & Physiological state & Animal description & Diet & $\Delta^{15} \mathrm{~N}$ & Sample type \\
\hline Present study ${ }^{\star}$ & Growing & Growing heifers & Grass silage/concentrates & 3.58 & Plasma \\
\hline Present study† & Growing & Growing heifers & Grass silage/concentrates & 3.90 & Plasma \\
\hline Steele \& Daniel ${ }^{(36)}$ & Growing/mature & Angus steers & Ryegrass/white clover silage & $4 \cdot 2$ & Blood \\
\hline Sponheimer et al. ${ }^{(30)} \ddagger$ & Growing/mature & Cattle & Lucerne hay & 4 & Blood \\
\hline Koyama et al. ${ }^{(37)}$ & Growing/mature & Beef cattle & Rice straw & 3.8 & Blood \\
\hline Sponheimer et al. ${ }^{(30)} \ddagger$ & Growing/mature & Goats & Lucerne hay & 4.7 & Plasma \\
\hline Sutoh $^{(38)}$ & Mature & Goats, 2-year-old females & Lucerne hay cubes & 4.8 & Plasma \\
\hline Sutoh et al. ${ }^{(39)}$ & Mature & Wethers, 4 years old & Lucerne hay cubes & 6.94 & Plasma protein \\
\hline Darr \& Hewitt ${ }^{(40)}$ & Mature & Deer, 2-year-old males & Lucerne & $5 \cdot 67$ & Serum \\
\hline Darr \& Hewitt ${ }^{(40)}$ & Mature & Deer, 2-year-old males & Lucerne/maize (3:2) & $6 \cdot 2$ & Serum \\
\hline Koyama et al. ${ }^{(37)}$ & Lactating & Beef cows, milking & Pasture & 2.59 & Blood \\
\hline Sutoh et al. ${ }^{(39)}$ & Lactating & Lactating dairy cows & Forage/concentrates (1:1) & $2 \cdot 37$ & Plasma \\
\hline Cheng et al. ${ }^{(41)}$ & Lactating & Lactating dairy cows & Grass & 3.19 & Plasma \\
\hline Jenkins et al. ${ }^{(42)} \ddagger$ & Lactating & Sheep, early lactation & Hay & $5 \cdot 1$ & Plasma \\
\hline Jenkins et al. ${ }^{(42)} \ddagger$ & Lactating & Sheep, early lactation & & 4.5 & Plasma \\
\hline Jenkins et al. ${ }^{(42)}{ }^{+}$ & Neonate & Deer calves, $12-14 \mathrm{~d}$ old & Milk & 1.9 & Plasma \\
\hline Jenkins et al. ${ }^{(42)}$ & Neonate & Lambs, $12-14 \mathrm{~d}$ old & Milk & 3 & Plasma \\
\hline Jenkins et al. ${ }^{(42)}$ & Neonate & Moose calves, $<3$ months old & Milk & 1.5 & Plasma \\
\hline
\end{tabular}

* Whole population $(n 84)$

† Subset heifers averaged over time ( $n$ 20)

¥Unpublished results cited by Robbins et al. ${ }^{(43)}$. 


\section{Repeatability of nitrogen isotopic fractionation measurements}

In the present study, we demonstrated a consistent and repeatable strong relationship between $\mathrm{N}$ isotopic fractionation and FCE that will be useful for application of the approach in animal breeding. The correlation between plasma $\delta^{15} \mathrm{~N}$ at the different time points was also usefully strong. It appears that FCE remained constant over the measurement period and $\Delta^{15} \mathrm{~N}$ values remained stable despite the natural variation in growth rate that may have been increased because of heifers entering puberty at different stages during the experiment ${ }^{(34)}$.

\section{Relationship of nitrogen isotopic fractionation with feed conversion efficiency}

$\mathrm{N}$ isotopic fractionation $\left(\Delta^{15} \mathrm{~N}\right)$ was a good indicator of FCE in the present study, and it seems likely that this relationship was driven by the partitioning of $\mathrm{N}$ between live-weight gain and excretion in the urine. The negative relationship between $\Delta \Delta^{15} \mathrm{~N}$ and FCE is consistent with the increased $\Delta^{15} \mathrm{~N}$ when cattle and goats were fed diets containing higher protein levels ${ }^{(30)}$. The relationship between $\Delta^{15} \mathrm{~N}$ and FCE was probably stronger for the subset of twenty animals because they were more homogeneous (lower sD for live weight) and genetically more similar. Plasma $\delta^{15} \mathrm{~N}$ differed between the breed and sire groups, providing preliminary evidence that it will be possible to use this approach to select for beef cattle with higher FCE. N isotopic fractionation only explained $1 \%$ of the variance of RFI. As expected, $\mathrm{N}$ isotopic fractionation was more related to simple measures of input and output (i.e. FCE) than complex measures of efficiency such as RFI.

Since the composition of live-weight gain was not measured in the present study, it is likely that some of the unexplained variation in the relationships between plasma $\delta^{15} \mathrm{~N}$ or $\Delta^{15} \mathrm{~N}$ and FCE results from the variation in the relationship between NUE and FCE. The inclusion of $W^{075}$ accounted for some of the variation in the relationship between $\Delta^{15} \mathrm{~N}$ and FCE (Table 2) because the $\mathrm{N}$ content of live-weight gain declines as animals grow $^{(35)}$. Average values for the protein content of live-weight gain are $6.3 \%$ lower for $450 \mathrm{~kg}$ cattle in comparison with $250 \mathrm{~kg}$ cattle ${ }^{(35)}$, implying a reduction in NUE at the same FCE. Fractionation of $\mathrm{N}$ isotopes in the rumen could explain additional variation ${ }^{(25,36)}$, though the strong relationships with FCE and use of a consistent diet suggest that any effect would have been small.

$\mathrm{N}$ isotopic fractionation $\left(\Delta^{15} \mathrm{~N}\right)$ explained more variation in FCE than single blood metabolites or hormones that were used to predict RFI in earlier studies. In these animals, Lawrence et $a l .{ }^{(16)}$ found no significant relationships between blood metabolites and RFI, except for creatinine. Kelly et al. ${ }^{(15)}$ reported weak relationships between feed conversion ratio and plasma leptin $\left(r^{2} 0 \cdot 23\right)$, urea $\left(r^{2} 0 \cdot 18\right)$ and NEFA $\left(r^{2} 0 \cdot 10\right)$ in heifers, while Richardson et al. ${ }^{(14)}$ found weak relationships between feed conversion ratio and plasma glucose $\left(r^{2} 0 \cdot 21\right)$, aspartate aminotransferase $\left(r^{2} 0 \cdot 20\right)$ and albumin $\left(r^{2} 0 \cdot 23\right)$ in steers.

The partitioning of $\mathrm{N}$ between protein (muscle tissue or milk) and urea is affected by protein supply and protein quality $^{(22,29)}$, and both aspects have been used to explain differences in $\mathrm{N}$ isotopic fractionation. The first effect suggests that as dietary protein supply increases, an increasing proportion of $\mathrm{N}$ is directed to urine, so that fractionation increases. The second effect emphasises increased fractionation as a result of decreased protein quality and consequent increased losses as urinary N. In the present study, animals received the same diet, so the effects must be mainly due to the between-animal variation in feed utilisation. The between-animal variation in $\mathrm{N}$ partitioning depends on the ability of individual animals to utilise protein, which will depend on their genetic make-up and management history. There was a weak relationship between plasma urea $\mathrm{N}$ and FCE in the present study and a low level of urea $\mathrm{N}$ relative to protein $\mathrm{N}$ in plasma, which suggests that the urea fraction of plasma would not affect the relationship between FCE and plasma $\delta^{15} \mathrm{~N}$. N fractionation in the present study was able to predict the animal variation associated with FCE.

\section{Conclusion}

We have demonstrated a highly significant negative relationship between $\mathrm{N}$ isotopic fractionation between plasma and the diet $\left(\Delta^{15} \mathrm{~N}\right)$ and feed efficiency in growing beef heifers. This $\mathrm{N}$ isotopic fractionation effect changed only slowly over time, which would be useful for application in cattle breeding. $\mathrm{N}$ isotopic fractionation may be useful in evaluating feed efficiency without measuring feed intake, and even diet composition, provided that animals are fed with identical diets, and be used to compare the nutrient-use efficiency of different feeds.

\section{Acknowledgements}

The authors acknowledge the skilled technical assistance of J. Larkin and E. Mulligan.

The present study was financially supported by the European Union (Marie Curie International Reintegration Grant FP7-PEOPLE-IRG-2008-239241) and as part of the Department of Agriculture, Food and the Marine grant in aid to Teagasc. The funders had no role in the design, analysis or writing of this article.

The authors' responsibilities were as follows: N. M. W., M. M., G. R. E. and R. J. D. were involved in the design of the study, data analysis and preparation of the manuscript; N. M. W. conducted additional laboratory analysis and prepared the first draft of the manuscript. All authors read and approved the final manuscript.

None of the authors has any conflict of interest.

\section{References}

1. Gill M, Smith P \& Wilkinson JM (2010) Mitigating climate change: the role of domestic livestock. Animal 4, 323-333.

2. Powell JM, MacLeod M, Vellinga TV, et al. (2013) Feed-milkmanure nitrogen relationships in global dairy production systems. Livest Sci 152, 261-272.

3. Ashfield A, Crosson P \& Wallace M (2013) Simulation modelling of temperate grassland based dairy calf to beef production systems. Agr Syst 115, 41-50. 
4. Herd RM, Oddy VH \& Richardson EC (2004) Biological basis for residual feed intake in beef cattle. 1. Review of potential mechanisms. Aust J Exp Agr 44, 423-430.

5. Case LA, Wood BJ \& Miller SP (2012) The genetic parameters of feed efficiency and its component traits in the turkey (Meleagris gallopavo). Genet Sel Evol 44, 2.

6. Archer JA, Richardson EC, Herd RM, et al. (1999) Potential for selection to improve efficiency of feed use in beef cattle: a review. Aust J Agr Res 50, 147-161.

7. Crews DH (2005) Genetics of efficient feed utilization and national cattle evaluation: a review. Genet Mol Res 4, 152-165.

8. Koch RM, Swiger LA, Chambers D, et al. (1963) Efficiency of feed use in beef cattle. J Anim Sci 22, 486-494.

9. Herd RM, Archer JA \& Arthur PF (2003) Reducing the cost of beef production through genetic improvement in residual feed intake: opportunity and challenges to application. J Anim Sci 81, E9-E17.

10. Archer JA, Arthur PF, Herd RM, et al. (1997) Optimum post weaning test for measurement of growth rate, feed intake and feed efficiency in British breed cattle. J Anim Sci 75, 2024-2032.

11. Dewhurst RJ, Moorby JM, Dhanoa MS, et al. (2000) Effects of altering energy and protein supply to dairy cows during the dry period. 1. Intake, body condition, and milk production. J Dairy Sci 83, 1782-1794.

12. Moore SS, Mujibi FD \& Sherman EL (2009) Molecular basis for residual feed intake in beef cattle. J Anim Sci 87, E41-E47.

13. Robinson DL \& Oddy VH (2004) Genetic parameters for feed efficiency, fatness, muscle area and feeding behaviour of feedlot finished beef cattle. Livest Prod Sci 90, 255-270.

14. Richardson EC, Herd RM, Archer JA, et al. (2004) Metabolic differences in Angus steers divergently selected for residual feed intake. Aust J Exp Agr 44, 441-452.

15. Kelly AK, McGee M, Crews DH, et al. (2010) Effect of divergence in residual feed intake on feeding behavior, blood metabolic variables, and body composition traits in growing beef heifers. J Anim Sci 88, 109-123.

16. Lawrence P, Kenny DA, Earley B, et al. (2012) Grazed grass herbage intake and performance of beef heifers with predetermined phenotypic residual feed intake classification. Animal 6, 1648-1661.

17. Herd RM \& Arthur PF (2009) Physiological basis for residual feed intake. J Anim Sci 87, E64-E71.

18. Arthur PF, Archer JA \& Herd RM (2004) Feed intake and efficiency in beef cattle: overview of recent Australian research and challenges for the future. Aust J Exp Agr 44, 361-369.

19. Macko SA, Fogel-Estep ML, Engel MH, et al. (1986) Kinetic fractionation of stable nitrogen isotopes during amino acid transamination. Geochim Cosmochim Acta 50, 2143-2146.

20. Minagawa $M \&$ Wada E (1984) Stepwise enrichment of ${ }^{15} \mathrm{~N}$ along food chains: further evidence and the relation between $\delta^{15} \mathrm{~N}$ and animal age. Geochim Cosmochim Acta $\mathbf{4 8}$, $1135-1141$.

21. Sutoh M, Koyama T \& Yoneyama T (1987) Variations of natural ${ }^{15} \mathrm{~N}$ abundance in the tissues and digesta of domestic animals. Radioisotopes 36, 74-77.

22. Poupin N, Bos C, Mariotti F, et al. (2011) The nature of the dietary protein impacts the tissue-to-diet ${ }^{15} \mathrm{~N}$ discrimination factors in laboratory rats. PLoS One 11, e28046.

23. Balter V, Simon L \& Fouillet H (2006) Box-modelling of ${ }^{15} \mathrm{~N} /{ }^{14} \mathrm{~N}$ in mammals. Ecophysiology 147, 212-222.

24. Martinez del Rio C \& Carleton SA (2012) How fast and how faithful: the dynamics of isotopic incorporation into animal tissues. J Mammal 93, 353-359.
25. Wattiaux MA \& Reed JD (1995) Fractionation of nitrogen isotopes by mixed ruminal bacteria. J Anim Sci 73, 257-266.

26. Smith JJ, Millar JS, Longstaffe FJ, et al. (2010) The effect of metabolic rate on stable carbon and nitrogen isotope compositions in deer mice, Peromyscus maniculatus. Can $J$ Zool 88, 36-42.

27. De Niro MJ \& Epstein S (1981) Influence of diet on the distribution of nitrogen isotopes in animals. Geochim Cosmochim Acta 45, 341-351.

28. Caut S, Angulo E \& Courchamp F (2009) Variation in discrimination factors $\left(\Delta^{15} \mathrm{~N}\right.$ and $\left.\Delta^{13} \mathrm{C}\right)$ : the effect of diet isotopic values and applications for diet reconstruction. $J$ Appl Ecol 46, 443-453

29. Sick H, Roos N, Saggau E, et al. (1997) Amino acid utilization and isotope discrimination of amino acid nitrogen in nitrogen metabolism of rat liver in vivo. Z Ernabrungswiss 36, 340-346.

30. Sponheimer M, Robinson T, Ayliffe L, et al. (2003) Nitrogen isotopes in mammalian herbivores: hair $\delta^{15} \mathrm{~N}$ values from a controlled feeding study. Int J Osteoarchaeol 13, 80-87.

31. Cheng L, Kim EJ, Merry RJ, et al. (2011) Nitrogen partitioning and isotopic fractionation in dairy cows consuming diets based on a range of contrasting forages. J Dairy Sci 94, 2031-2041.

32. Wheadon NM, Edwards GR \& Dewhurst RJ (2012) Comparison of nitrogen-use efficiency and energy conversion efficiency as measures of feed conversion efficiency in Holstein-Friesian cows over an entire lactation cycle. In Proceedings of the British Society of Animal Science. Edinburgh: British Society of Animal Science.

33. Owens D, McGee M, Boland T, et al. (2008) Intake, rumen fermentation and nutrient flow to the omasum in beef cattle fed grass silage fortified with sucrose and/or supplemented with concentrate. Anim Feed Sci Technol 144, 23-43.

34. Ciccioli NH, Charles-Edwards SL, Floyd C, et al. (2005) Incidence of puberty in beef heifers fed high-or low-starch diets for different periods before breeding. J Anim Sci 83, $2653-2662$

35. Agricultural Research Council (1980) The Nutrient Requirements of Ruminant Livestock. Farnham Royal: Commonwealth Agricultural Bureaux.

36. Steele KW \& Daniel RM (1978) Fractionation of nitrogen isotopes by animals: a further complication to the use of variations in the natural abundance of ${ }^{15} \mathrm{~N}$ for tracer studies. J Agr Sci 90, 7-9.

37. Koyama T, Madoka S \& Tadakatu Y (1985) Fractionation of nitrogen isotopes by domestic animals. Jpn J Zootechnical Sci 56, 361-363.

38. Sutoh M (1989) Comparison of natural abundance of ${ }^{15} \mathrm{~N}$ between diet, rumen contents and blood plasma. Asian Austral J Anim Sci 2, 548-549.

39. Sutoh M, Obara Y \& Yoneyama T (1993) The effect of feeding regimen and dietary sucrose supplementation on natural abundance of ${ }^{15} \mathrm{~N}$ in some components of ruminal fluid and plasma of sheep. J Anim Sci 71, 226-231.

40. Darr RL \& Hewitt DG (2008) Stable isotope trophic shifts in white-tailed deer. J Wildlife Manage 72, 1525-1531.

41. Cheng L, Sheahan AJ, Gibbs SJ, et al. (2013) Technical Note: nitrogen isotopic fractionation can be used to predict nitrogen-use efficiency in dairy cows fed temperature pasture. J Anim Sci 91, 5785-5788.

42. Jenkins SG, Partridge ST, Stephenson TR, et al. (2001) Nitrogen and carbon isotope fractionation between mothers, neonate and nursing offspring. Oecologia 129, 336-341.

43. Robbins T, Felicetti LA \& Sponheimer M (2005) The effect of dietary protein quality on nitrogen isotope discrimination in mammals and birds. Oecologia 144, 534-540. 